\title{
Dış Ticarette Yaşanan Sorunların Batı Karadeniz Bölgesi Orman Ürünleri Sanayisinde Analizi
}

\author{
Tark GEDİK ${ }^{1 *}$, Özge ÖZTÜRK² \\ ${ }^{1}$ Düzce Üniversitesi, Orman Fakültesi, Orman Endüstri Mühendisliği Bölümü, 81620, Düzce, Türkiye. \\ ${ }^{2}$ Düzce Üniversitesi, Fen Bilimleri Enstitüsü, Orman Endüstri Mühendisliği ABD, 81620, Düzce, Türkiye.
}

\begin{abstract}
Öz
Temel amacı kar elde etmek olan üretim işletmelerinin uluslararası ticarette var oldukları sürece yüksek kar elde edebilecekleri bellidir. Yapılan bu çalı̧̧ma ile Batı Karadeniz Bölgesi illerinde faaliyette bulunan orman ürünleri sanayi işletmelerinin dış ticaret yaparken yaşadıkları sorunların araştırılması amaçlanmıştır. $\mathrm{Bu}$ amaç doğrultusunda 2019 yılında Batı Karadeniz Bölgesi illerindeki orman ürünleri sanayisinde olan ve 10 ve daha fazla çalş̧ana sahip 237 işletme çalışmanın evrenini oluşturmuş ve 58 işletmeden anket yardımıla veri elde edilmiştir. Veri elde etme aracı olarak kullanılan ankette işletmelerin dış ticaret yaparken yaşadıkları sorunlar analiz edilmiştir. Elde edilen anketlerin istatistiksel değerlendirmeleri sonucunda işletmelerin \%51.7'sinin dış ticaretle ilgili olarak ayrı bir eleman çalışırıdığ 1 belirlenmiş̧ir. İşletmelerin \%44.8'i dış ticaret yaparken herhangi bir kurumdan ya da işletmeden destek aldıkları belirlenmiş̧tir. Yapılan analizler sonucunda dış ticaret yapan işletmelerin dış ticarette en fazla yaşadıkları sorunların elverişsiz kur oranları ile dış ticaret yapılan ülkelerle ilgili siyasi ilişkiler düzeyinin dış ticareti etkilediği belirlenmiştir. İşletmelerin dış ticaret uygulamaları esnas ında karşılaştıkları sorunların başında maliyetlerle ilgili sorunlar ile vergiler ve teşvikler ile ilgili sorunlar gelmektedir.
\end{abstract}

Anahtar Kelimeler: Dış ticaret sorunları, Batı Karadeniz Bölgesi, orman ürünleri sanayi.

\section{Analysis of the Problems in Foreign Trade in the Western Black Sea Region Forest Products Industry}

\begin{abstract}
It is obvious that production enterprises, whose main purpose is to make profit, can earn high profits as long as they exist in international trade. With this study, it is aimed to investigate the problems experienced by forest products industry enterprises operating in the provinces of the Western Black Sea Region while doing foreign trade. In line with this purpose, 237 enterprises in the forest products industry in the provinces of the Westem Black Sea Region and having 10 or more employees formed the universe of the study and data were obtained from 58 enterprises with the help of a questionnaire. In the questionnaire, which is used as a data acquisition tool, the problems faced by businesses in foreign trade were analyzed. As a result of the statistical evaluations of the obtained surveys, it has been determined that $51.7 \%$ of the enterprises employ a separate employee related to foreign trade. It has been determined that $44.8 \%$ of the enterprises receive support from any institution or business while doing foreign trade. As a result of the analysis, it has been determined that the most common problems experienced by foreign trade businesses in foreign trade are unfavorable exchange rates and the level of political relations with foreign trade countries. The main problems faced by businesses during their foreign trade practices are problems related to costs, and problems with taxes and incentives.
\end{abstract}

Keywords: Foreign trade, problems, Western Black Sea Region, forest product industry. 


\section{Giriş}

Bağımsız ülkeler arasında mal ve hizmet ticaretinin tümü dış ticaret olarak isimlendirilebilir. Aslında dış ticaret, malların ve sermayenin ulusal sınırların dışına ithalat ya da ihracat yoluyla değiş tokuş yapılmasıdır. Bu değgiş tokuştan dolayı dış ticaret ulusal ekonominin kalkınması için önemli bir yere sahiptir.

Dış ticaret iki ya da daha fazla devlet arasında gerçekleşen bir ticaret olarak tanımlansa bile (Suri et al. 2006) yani dış ticaretin gerçekleşebilmesi için belli ülke sınırlarının olması gerekse bile bazen söz konusu ülke sınırları yerine ekonomik birlikler de kurulabilir. Bu gibi durumlarda dış ticaret yapabilmek için siyasi sınırların olmas 1 zorunluluk oluşturmaz. Kurulan ekonomik birliklerle de diş ticaret gerçekleştirebilmektedir (Köksal 2016). Ülkeler dış ticarette alıcı ya da satıcı olarak yer almakta, alıcı ülkelerin yaptığı ticaret ithalat olarak, satıcı ülkelerin yaptığı ticaret ise ihracat olarak adlandırılmaktadır (Bakan 2012). Dış ticaret döviz girdisi sağlaması bakımından dış ticaret yapan ülkelerin en önemli gelir kaynaklarından biridir (Ketboğa 2020).

Hiçbir ülke kendi sahip oldukları kaynakları tamamen kullanabilme ve ihtiyaçlarını karşılayabilme gücüne sahip değildir. Dış ticaret ile herhangi bir mal veya mal gurubu bir ülkeden başka bir ülkeye geçmekte bunun karşılı̆̆ında da bir diğer ülkeden bir mal veya mal gurubu o ülkeye girmektedir (Kabal 2007). Dünyadaki gelişmiş, az gelişmiş ya da gelişmekte olan ülkeler arasında ticaret yapılması dünyadaki düzenin gereği olarak dış ticareti önemli hale getirmektedir (Karluk 1991). İşletmelerin dış ticarete yönelmeleri sonucunda elde edecekleri döviz girdileri ile ülke ekonomilerine katkıda bulunacakları ve istihdam yaratacakları aşikârdır (Erdoğan and Develioğlu 2009). Ancak, Aktaş'ın da (2017) dediği gibi ülkelerin gelişmişlik ve refah düzeylerin i belirleyebilmek için, dış ticarette artış eğiliminde olan bir trend olması gerekmektedir. Bunun için de ülkelerdeki üretim miktar ve çeşitliliğinin yüksek ve esnek olması gerekmektedir. Üretim miktarının artması için öncelikle üretim becerisinin artması ve gelişmesi gerekmektedir.

Literatürde işletmelerin dış ticaret yaparken yaşadıkları sorunların analizine dönük fazlaca çalışma bulunmaktadır. $\mathrm{Bu}$ çalışmalarda dış ticaret yapan işletmelerin yaşadıkları temel sorunlar iç sorunlar ve dış sorunlar olarak dile getirilmiştir. İç sorunlar olarak örgütsel nedenlerden kaynaklanan sorunlar ön plana çıkarılırken, örgüt dışından kaynaklanan sorunlar da dış sorunlar olarak dile getirilmektedir (Leoniduo 1995; Erdoğan and Develioğlu 2009; Köksal and Kettaneh 2011; Kaymak 2015; Takım 2015; Çetinkaya Bozkurt and Tunç 2018; Bahçeci 2019).

Ketboğa (2020) tarafindan yapılan çalışmada dış ticarette yaşanılan sorunlar çok boyutlu olarak ele alınmıştır. Çalışmada işletmelerin diş ticarette yaşadıkları temel sorunlar; dış ticaret açığı sorunu, dış ticarette ortaya çıkan kur riski, dış ticarette ödeme şekillerine göre ortaya çıkan yapısal sorunlar, ihracatın ithalata bağımı olmasından kaynaklı ortaya çıkan sorunlar, döviz kuru politikalarından kaynaklı ortaya çıkan yapısal sorunlar, Gümrük Birliği antlaşmaları ve kısıtlayıcı hükümlerinden kaynaklanan sorunlar, dış ticarette yaşanan bürokratik engeller, gümrük vergileri ve kota uygulamalarından kaynaklı ortaya çıkan sorunlar, nitelikli dış ticaret eleman 1 eksikliğinden kaynaklı yaşanan sorunlar ve dış ticaretin finansman sorunu şeklinde özetlenmiştir.

TUİK (2020) verilerine göre (2013-2019 yılları arası) Türkiye'nin ithalat ve ihracat rakamlarında ithalat hacminin ihracat değerinden fazla olduğu görülmektedir ve bu durum ülkemizin dış ticaret açığının olduğunun bir göstergesidir. Türkiye'nin 2019 yılında en fazla ihracat yaptı̆̆ 1 ilk beş ülke Almanya, İngiltere, Irak, İtalya ve ABD'dir. Türkiye'nin 2019 yılında en fazla ithalat yaptığ 1 ilk beş ülke ise Rusya, Almanya, Çin ABD ve İtalya'dır.

Akyüz ve arkadaşları (2006) tarafindan yapılan çalışmada orman ürünleri sanayi işletmelerinin imalat sanayi içinde etkin bir rol üstlendiği belirtilmiş ve dış ticarete önem verilmesi ile de ülkemizin rekabet yapılanmas ındaki konumunun güçlendirilebileceği belirtilmiştir. Yıldırım ve arkadaşları (2008) yaptıkları çalışmada Türkiye orman ürünleri sanayinin daha ileri seviyelere gelebilmesi için yapılması gerekenleri sıralamış ve uluslararası alanda pazar araştırma çalışmalarının hızlandırılması ve uygun pazarlama bileşenleri yardımıyla değişik ülke pazarlarına girilmesine önem verilmesi gerektiğini belirtmişlerdir.

Türkiye İstatistik Kurumu (TUİK 2016) verilerine göre ülkemizdeki işletmelerin yaklaşık \%99,9'u küçük ve orta büyüklükteki (KOBI) işletmelerden oluşmaktadır. KOBI'ler istihdamın \%76'sını, yatırımların da yaklaşık \%50'sini sağlamaktadır. Bu nedenle KOBİ'lerin sorunlarına çözüm bulmak ülkemiz ekonomisi ve toplumun sosyal yaşamı açısından büyük önem taşımaktadır. Orman ürünleri sanayisi de KOBİ niteliğinde işletmelerden oluşmaktadır. Yapılan bu çalışma ile Batı Karadeniz Bölgesinde faaliyette bulunan orman ürünleri sanayi işletmelerinin dış ticaret yaparken yaşadıkları sorunlar araştırılmaya çalışılmıştır. 


\section{Araştırma Yöntemi}

Batı Karadeniz Bölgesinde faaliyette bulunan ve 10 ve daha fazla çalışanı olan işletmelerin dış ticarette yaşadıkları sorunların araştırıldığı bu çalışmada evreni Bartın, Bolu, Düzce Kastamonu ve Karabük illerindeki orman ürünleri sanayisi işletmeleri oluşturmaktadır. 2019 yılı Bartın, Bolu, Düzce Kastamonu ve Karabük illerindeki Ticaret ve Sanayi Odalarına kayıtlı (Anonim 2019) bulunan 10 ve daha fazla çalışanı olan 237 işletme çalışma evrenini oluşturmuştur. Çalışma Covid-19 pandemi sürecinde gerçekleştirilmeye çalışılmış olmasından dolayı \%90 güven düzeyi ve \%10 hata oranı ile örneklem hesaplanmıştır. Yapılan hesaplamalar sonucunda ulaşılması gereken minimum örneklem 53 olarak belirlenmiş ve çalışma kapsamında 58 işletmeye ulaşılmıştır. Ulaşılan bu örneklemin istatistiksel olarak evreni temsil ettiği sonucuna varılmıştır (Lemeshow et al. 1990).

Çalışmada 4 farklı bölümden oluşan bir anketten yararlanılmıştır. Çalışma kapsamında kullanılan anket 13 farklı soru ve 28 yargıdan oluşmaktadır (Çoban 2005; Yıldırım et al. 2005; Sönmez and Arslan 2007; Kumbas 2017; Tunç and Kaya 2017; Çetinkaya Bozkurt and Tunç 2018). Kullanılan anket formunun birinci bölümünde ulaş ılan işletmeler hakkında bazı özellikler 5 soru ile sorgulanmıştır. Anket formunun ikinci bölümünde işletmelerin dış ticaret düzeyleri ile ilgili 6 soruya yer verilmiştir. Kullanılan anketin üçüncü bölümünde işletmelerin dış ticaret yaparken yaşadıkları sorunlar 9 soru ile sorgulanmıştır. Anketin dördüncü ve son bölümünde dış ticaret yapan işletmelerin dış ticaret uygulamalarında karșılaștıkları sorunlar 8 soru ile analiz edilmeye çalıșılmıștır. Kullanılan ankette hem açık uçlu hem de likert tarzı sorulara yer verilmiş olup, kullanılan likert ölçeği 5'li likerttir (1: Çok düşük, 2: Düşük, 3: Orta, 4: Yüksek, 5: Çok yüksek).

Çalışma kapsamında el edilen anket sonuçları SPSS (2003) paket programında kodlanarak çalışmanın veri seti oluşturulmuştur. Oluşturulan bu veri seti ile anket formunda yer alan soruların tanımlayıcı istatistikleri (ortalama, standart sapma ve frekans değerleri), anlamlı gruplar ya da kümeler oluşturabilmek için kümeleme analizi, çalışmada ele alınan dış ticaret sorunlarının işletmelerin bazı özelliklerine göre ilişki gösterip göstermediğini belirlemek için de Ki-kare analizinden yararlanılmıştır. Ayrıca çalışmada kullanılan anketin geçerlilik ve güvenilirlik analizine de bakılmıştır.

Çalışmada kullanılan ölçeğin geçerlilik ve güvenilirlik analizi Tablo 1'de gösterildiği gibi belirlenmiştir. Güvenilirlik analizi için Cronbach Alpha katsayısına ve geçerlilik analizi içinde örnekleme yeterlilik ölçüsüne bakılmıştır (KMO). Yapılan istatistiksel analizler sonucunda alpha katsayısının tüm ölçek için 0.867 olduğu, dış ticarette yaşanan sorunlar ölçeğinde 0.813; dış ticaret uygulamalarında yaşanan sorunlar ölçeğinde ise 0.816 olduğu belirlenmiştir. Elde edilen bu sonuçların güvenilirlik için bir sorun teşkil etmediği görülmüştür (Özdamar 2002; Kalayc1 2009). Ölçeğin geçerlilik için test edilen KMO değeri 0.717; Barlett küresellik değeri 466.911 ve p değeri de 0.000 olarak hesaplanmıştır. Elde edilen bu sonuçların da geçerlilik açısından bir sorun teşkil etmediğ $i$ sonucuna varılmıştır (Özdamar 2002; Kalaycı 2009).

Tablo 1. Geçerlilik ve güvenilirlik analizi sonuçları

\begin{tabular}{lcc}
\hline \multicolumn{1}{c}{ Alt Boyutlar } & Güvenilirlik & Geçerlilik \\
\hline Dış ticarette yaşanan sorunlar & 0.813 & \\
Diş ticaret uygulamalarında yaşanan sorunlar & 0.816 & 0.717 \\
Ölçek toplamı & $\mathbf{0 . 8 6 7}$ & \\
\hline
\end{tabular}

\section{Bulgular}

\section{1. İşletmeler Hakkında Bilgiler}

Çalışma kapsamında veri alınan işletmelerin \%21.8'i mobilya, \%32.7’si kereste ve parke ve \%45.5'i de diğer orman ürünleri alanında faaliyette bulunmaktadır. İşletmelerin \%58.6'sının 15 yıl ve daha fazla süredir faaliyette olduğu belirlenirken, \%12.1'i 5 yıl ve daha az süredir, \%13.8’i 6-10 yıldır ve \%15.5’i de 11-15 yıldır faaliyette oldukları belirlenmiştir. İşletmelerin hukuki yapıları irdelendiğinde $\% 50$ oranında limitet şirket, $\% 37.9$ oranında anonim şirket, \%12.1 oranında da şahıs işletmesi statüsünde oldukları tespit edilmiştir.

İşletmelerde çalışan sayısı irdelendiğinde işletmelerin \%31'inin 10-25 arası çalışanı olduğu, \%22.4'ünün 26-50 arası çalışanı olduğu, \%23.2 oranında 51-100 arası çalışanı olduğu ve \%22.4 oranında da 101 ve daha fazla çalışanı olduğu belirlenmiştir. En az çalışanı olan işletmede 11, en fazla çalışanı olan işletmede ise 790 çalışanın olduğu ve ortalama çalışan sayısının da 82.3 çalışan olduğu tespit edilmiştir. 
İşletmelerde en az 1 tane en fazla da 33 tane büro elemanı çalıştı̆̆ 1 , en az 1 tane en fazla da 30 tane ustabaşını bulunduğu ve en yoğun şekilde işletmelerde işçilerin çalıştırıldığ 1 (en fazla 700 çalışan) tespit edilmiştir.

İşletmelerin \%48,3'ünde dış ticaretle ilgili olarak ayrı bir eleman çalıştırılmadığı tespit edilirken, 1 tane dış ticaret elemanı çalıştıran işletme oranı \%27.6, 2 tane dış ticaret elemanı çalıştıran işletme oranı \%15.5, 3 ve daha fazla dış ticaret elemanı çalıştıran işletme oranı da \%8.6 olarak belirlenmiştir. Öztürk ve Sandalcılar (2018) tarafından Doğu Karadeniz Bölgesinde yapılan çalışmada ulaşılan işletmelerin \%65.38'inde diş ticaret eğitimi almış çalışanın bulunduğu belirtilmiştir.

İşletmelerin tedarik kaynakları irdelendiğinde \%100 ulusal kaynaklı olduğunu belirten işletme oranı \%46.6 iken, sadece ulus lararası kaynaklı olduğunu belirten işletme oranı da \%1.7 (1 işletme) olarak tespit edilmiştir.

İşletmelerin \%46.6's1 5 yıl ve daha az süredir diş ticaret yaptıklarını belirtirken, \%17.2'si 6-10 y1ldır, \%12.1'i 11-15 yıldır ve \%24.1'i de 15 yıl ve daha fazla süredir dış ticaret yaptıklarını belirtmişlerdir.

İşletmelerin en az 1, en fazla da 12 farklı ülkeyle dış ticaret yaptıkları belirlenmiştir. İşletmelerin \%41.4'ünün 3 ve daha az ülke ile \%39.6'sının 4-7 arası ülkeyle ve \%19'unun da 8-12 arası ülkeyle dış ticaret yaptıkları tespit edilmiştir.

İşletmelerin dış ticaret yaparken herhangi bir işletme/kurumdan destek alıp almadıkları irdelendiğinde \%44.8 oranında işletmenin herhangi bir kurumdan/işletmeden destek aldıkları belirlenmiştir. İşletmelerin dış ticaret sermaye şirketlerinden, yurtdışı temsilcilikle rinden ve diğ er iş letmelerden destek aldıkları belirlenirken, ihracatı geliştirme merkezinden (İGEME) destek almadıkları belirlenmiştir. Öztürk ve Sandalcılar (2018) tarafindan Doğu Karadeniz Bölgesinde yapılan çalışmada işletmelerin \%76,92'sinin dış ticaret faaliyetinde bulunurken kişi ya da kurumlardan destek aldıkları belirtilmiştir.

İşletmelerin dış ticarette kullandıkları ulaşım yolları irdelendiğinde işletmelerin \%82.8'i karayolu ile dış ticaret yaptıklarını belirtmişlerdir. Dış ticarette deniz yolundan yararlanan işletmelerin oranı \%62.1 olarak belirlenirken, havayolu ile dış ticaret yapanların oranı $\% 6.9$, demiryolu ile dış ticaret yapanların oranı 3,4 ve karma şekilde bu yolları kullanan işletmelerin oranı da \%1.7 olarak belirlenmiştir. Akan (2021) uluslararası ticarette en çok kullanılan ve rekabetinde en yoğun şekilde yaşandığı taşıma şeklinin karayolu ile taşımacilık olduğunu belirtmektedir. Tokol (1998) karayolu taşımacılı̆̆ının denizyolu ve demiryolu taşımacılı̆̆ına göre taşınan eşyaya zarar verme riskinin çok düşük olduğunu belirtmektedir.

İşletmelerin uluslararası ürün tes lim sözleşmelerinden gemi güvertesinde masrafsız tes lim olarak bilinen Free Of Board (FOB) ile tes lim şeklini \%44.8 oranında, "mal bedeli, sigorta ve navlun olarak bilinen Cost Insurance and Freight (CIF) tes lim şeklini \%44.8 oranında, taşıyıcıya masrafsız teslim olarak bilinen Free Carrier (FCA) teslim şeklini \%20.7 oranında ve taşıma bedeli ve sigorta ödenmiş teslim olarak bilinen Carriage and Insurance Paid To (CIP) teslim şeklini de \%8.6 oranında kullandıkları belirlenmiştir. Öztürk ve Sandalcılar (2018) tarafindan yapılan çalışmada 2002-2017 dönemlerine ait ortalama diş ticaret (ihracat/ithalat) ödeme yöntemlerinde ihracatın \%59,38'inde mal mukabili ödeme; \%18,55'inde vesaik mukabili ödeme; \%11,96'sında akreditifli ödeme; \%7,77'sinde peşin ödeme; \%0,34'ünde kabul kredili ödeme ve \%2'sinde de diğer ödeme yöntemlerinin kullanıldığı belirtilmiştir. Aynı çalışmada ithalat değerlerinde ise ortalama ithalatın \%44,11'inin peşin ödeme; \%25,68'inin mal mukabili ödeme; \%16,21'inin akreditifli ödeme; \%8,77'sinin vesaik mukabili ödeme; \%0,14'ünün kabul kredili ödeme; \%5,10’unun da diğer ödeme yöntemlerini kullandıkları belirtilmiştir.

İşletmelerin ihracat yapma şekilleri irdelendiğinde \%67.3 oranında doğrudan kendi markaları ile pazara ürün gönderdikleri belirlenmiştir. Bunun yanında işletmelerin \%22.4 oranında sipariş veren işletmeye ürünleri markasız satmakta, bu işletmeler kendi markalarını yurtdışında kendileri basaraksattıkları ve \%10.3 oranında da sipariş veren işletmelerin kendi markaları basılarak ihracat yapıldığı tespit edilmiştir.

\subsection{Dış Ticaret Yapılırken Işsletmelerin Yaşadıkları Temel Sorunların Istatistiksel Analizi}

Batı Karadeniz Bölgesi illerinde faaliyette bulunan orman ürünleri sanayi işletmelerinin dış ticaret yaparken yaşadıkları temel sorunların önem düzeylerine göre gruplanmasına ait değerlendirme sonuçlarında 9 farklı sorudan yararlanılmış ve elde edilen sonuçlar Tablo 3'de gösterilmiştir. İşletmelerin diş ticaret yaparken yaşadıkları sorunlara 9 soruluk veri setine uygulanan kümeleme analizi sonucunda istatistiks elolarak anlamlı bir gruplama 3 grup olarak ortaya çıkmıştır $(p<0,05)$. Ortaya çıkan 3 grubun final küme merkezleri 1 . Grup için 3.74; 2. Grup için 2.97 ve 3 . Grup için 2.10 olarak tespit edilmiştir. 
Tablo 3. İşletmelerin dış ticaret yaparken yaşadıkları temel sorunlar

\begin{tabular}{|c|c|c|c|c|}
\hline Sorunlar & $\overline{\mathrm{x}}$ & $\sigma$ & Küme & Uzaklık \\
\hline Elverişsiz kur oranlarından etkilenme & 3.91 & 1,19 & 1 & 0.17 \\
\hline Ülkeler aras1 siyasalilişkilerin dış ticareti etkilemesi & 3.91 & 1.29 & 1 & 0.17 \\
\hline Yabancı pazarlarda yoğun rekabetten etkilenme & 3.59 & 1.12 & 1 & 0.15 \\
\hline Devlet desteğive teşviklerin yetersizliği & 3.55 & 1.29 & 1 & 0.19 \\
\hline $\begin{array}{l}\text { Dış pazarlardaki dağıtıcı ve müşterilerle yeterince ticari ilişki } \\
\text { kurulamaması }\end{array}$ & 3.19 & 1.36 & 2 & 0.22 \\
\hline İhracata yönelik bürokratik işlemlerin çok uzun ve maliyetli olması & 3.10 & 1.50 & 2 & 0.13 \\
\hline Yurt dişındaki yasal düzenlemeler hakkında bilgi sahibi olunmaması & 2.83 & 1.42 & 2 & 0.14 \\
\hline İhracat finansmanı için yüksek çalışma sermayesine sahip olunmaması & 2.76 & 1.26 & 2 & 0.22 \\
\hline Sözleşmelerde bulunan bilgilerin eksik olmas 1 & 2.10 & 1.10 & 3 & 0.00 \\
\hline
\end{tabular}

Likert ölçek: 1 Etkilenme çok düşük, 2 Etkilenme düşük, 3 Etkilenme orta, 4 Etkilenme fazla, 5 Etkilenme çok fazla $\quad \overline{\mathrm{x}}$ : Aritmetik ortalama, $\sigma$ : Standart sapma

Yapılan istatistiksel analizler neticesinde Batı Karadeniz Bölgesi orman ürünleri sanayi işletmelerinin dış ticaret yaparken karşılaştıkları en önemli sorunların başında elverişsiz kur oranları gelmektedir. Bunun yanında dış ticaret yapılan ülkeler arası siyasi ilişkilerin dış ticareti etkilemesinden dolayı da işletmelerin büyük sorunlar yaşadığı belirlenmiştir. Sönmez ve Arslan (2007) tarafindan mobilya işletmeleri üzerinde yapıllan çalışmada da elverişsiz kur oranlarından işletmelerin yüksek derecede olumsuz etkilendiği belirlenmiştir. Ketboğa (2020) tarafindan Malatya ilinde dış ticaret yapan işletmeler üzerine yapılan çalışmada da kur riski ve ödeme șekilleri, kur politikaları, nitelikli eleman eksikliği dış ticarette yaşanan temel sorunlar arasında gösterilmiştir. Saatçı (2019) tarafindan yapılan ve Gaziantep, Şanluurfa ve Hatay illerindeki işletmelerin Arap Baharı öncesi ve sonrasındaki dış ticaretin irdelendiği çalışmada Arap Baharı sonrasıyapılan dış ticarette finansal açıdan sorunlar yaşandığı belirlenmiş̧tir. Bunun sebebi olarak da hem ülkeler arası politikaların değişmesini hem de ticari anlamda negatif yansımaların yaşandığını göstermişlerdir. Tunç ve Kaya (2017) tarafindan yapılan çalş̧mada da "Uluslararası siyasetteki olumsuz gelişmelerin ihracatı olumsuz etkilediğì" yargısı en yüksek oranda katılım gösterilen yargı olmuştur. Kumbas (2017) yaptığı çalşmada özellikle KOBİ'lerin Türkiye'ye sınır komşusu olan ülkelerde yaşanan ekonomik istikrars ızlktan dolayı ihracatta sorunlar yaşadığını belirtmiş̧tir. Yılmaz ve Eryılmaz (2021) tarafindan yapılan çalşşmada üçüncü dünya ülkeleri olarak adlandırlan az gelişmiş ya da gelişmemiş ülkelere yapılan ihracat miktarlarındaki yükselişin sebebi olarak hükümetlerin siyasiyakınlaşmalarının etkisinin olduğu belirtilmiştir.

Çalışma kapsamında ele alınan işletmelerin dış ticaret sözleşmelerini kısmen de olsa iyi yaptıkları söylenilebilir. Zira işletmelerin sözleşmelerde bulunan bilgilerde eksiklikten kaynaklı olarak düşük oranda dı̧ ticaret sorunu yaşadıkları tespit edilmiştir.

İşletmelerin faaliyet alanlarına göre dış ticaret yaparken yaşadıkları temel sorunlardan sözleşmelerde bulunan bilgi eksikliğinden sorun yaşama yargısı aras ında yapılan Ki-kare analizine göre istatistiksel olarak bir ilişki tespit edilmiştir $(\mathrm{p}<0,05)$. Yapılan analizler sonucunda kereste ve parke üreticilerinin bu sorunu en yüksek oranda yaşadıkları tespit edilmiştir.

İşletmelerin faaliyet sürelerine göre dış ticaret yaparken yaşadıkları temel sorunlardan devlet desteği ve teşviklerin yetersizliğinden kaynaklı olarak sorun yaşama yargısı arasında yapılan Ki-kare analizine göre is tatistiksel olarak bir ilişki tespit edilmiştir $(\mathrm{p}<0,05)$. Yapılan analizler sonucunda işletmelerin faaliyet süreleri arttıkça bu sorunun daha fazla yaşandığı ileri sürülmüşsür.

Batı Karadeniz Bölgesi illerindeki orman ürünleri sanayi işletmelerinin dış ticaret uygulamalarında karşıllaştıkları sorunların önem düzeylerine göre gruplandırılmasına ait değerlendirmede 8 farklı sorudan yararlanılmıştır. Yapılan analizler sonucunda elde edilen sonuçlar Tablo 4'de gösterilmiştir. İşletmelerin diş ticaret uygulamaları sırasında karşılaştıklanı sorunlara ait 8 soruluk veri setine uygulanan kümeleme analizi sonucunda istatistiksel olarak anlamlı bir gruplama 3 grup olarak ortaya çıkmışır $(p<0,05)$. Ortaya çıkan 3 grubun final küme merkezleri 1. Grup için 3.50; 2. Grup için 3.01 ve 3 . Grup için 2.73 olarak tespit edilmiştir. 
Tablo 3. İşletmelerin dış ticaret uygulamalarında karşılaştıkları sorunlar

\begin{tabular}{lcccc}
\hline Sorunlar & $\overline{\mathrm{x}}$ & $\sigma$ & Küme & Uzaklık \\
\hline Maliyetlerle ilgili sorunlar & 3.53 & 1.10 & 1 & 0.03 \\
Vergiler ve teşvikler ile ilgili sorunlar & 3.47 & 1.11 & 1 & 0.03 \\
Bürokrasiden kaynaklanan sorunlar & 3.07 & 1.37 & 2 & 0.06 \\
Finansal sorunlar & 2.98 & 1.24 & 2 & 0.03 \\
Hedef pazara girişte yaşanan sorunlar & 2.98 & 1.46 & 2 & 0.03 \\
Gümrüklerde karşılaşıిlan sorunlar & 2.79 & 1.30 & 3 & 0.06 \\
Lojistik ve nakliye sorunları & 2.71 & 1.37 & 3 & 0.02 \\
Tanıtım ve fuar ile ilgili sorunlar & 2.69 & 1.37 & 3 & 0.04 \\
\hline
\end{tabular}

Likert ölçek: 1: Sorun çok düşük, 2: Sorun düşük, 3: Sorun orta, 4: Sorun fazla, 5: Sorun çok fazla $\overline{\mathrm{x}}$ : Aritmetik ortalama, $\sigma$ : Standart sapma

Yapılan istatistiksel değerlendirmeler sonucunda işletmelerin dış ticaret uygulamaları sırasında karşılaştıkları sorunların başında maliyetlerle ilgili sorunlar gelmektedir. Dış ticaret uygulamalarında işletmelerin maliyet unsurundan sonra en yüksek oranda vergilerden ve uygulanan teşvik politikalarından kaynaklı sorunlar yaşadıkları belirlenmiştir. Çalışmada bürokrasiden kaynaklı ortaya çıkan sorunlar, finansal sorunlar ve hedef pazara girişte yaşanan sorunların ikinci düzeyde sorunlar arasında olduğu gözlemlenmiştir. Ketboğa (2020) tarafindan yapılan çalışmada da bürokratik engeller, kota ve vergi uygulamaları ve finansal sorunlar dış ticarette yaşanan temel sorunlar aras ında gösterilmiştir. Tunç ve Kaya (2017) tarafindan yapılan çalışmada da ulus lararası düzeyde reklam eksikliği ya da yetersizliğinin ihracatı negatif etkilediği belirtilmiştir.

Dış ticaret yapan orman ürünleri sanayi işletmelerinin işletmelerini ve ürünlerini tanıtım ve fuarlarda gösterilmesi noktasında en düşük oranda sorunlar yaşadıkları belirlenmiştir. Bunun yanında işletmelerin lojistik ve nakliye sorunları ile gümrüklerde karşılaştıkları sorunların da düşük düzeyde karşılaşılan sorunlar olduğu tespit edilmiştir. Akbulut ve Sekmen (2015), tarafindan yapılan çalışmada taşıma maliyetlerinin uluslararası ticaret üzerinde önemli bir etkiye sahip olduğu ileri sürülmüştür. Yapılan çalışmada taşıma maliyeti ile uluslararası ticaret arasında ters yönlü bir iliş ki tespit edilmiştir.

İşletmelerin faaliyet alanlarına göre dış ticaret uygulamaları arasında yer alan maliyetlerle ilgili sorunlar yaşama ve bürokrasiden kaynaklanan sorunlar yaşama yargıları arasında yapılan Ki-kare analizine göre istatistiksel olarak bir ilişki tespit edilmiştir $(\mathrm{p}<0,05)$. Yapılan analizler sonucunda kereste ve parke üreticilerinin maliyetlerle ilgili olarak daha yüksek oranda sorun yaşadıkları belirlenmiştir. Bürokrasiden kaynaklı yaşanan sorunlarda ise mobilya işletmelerinin en az sorun yaşadıkları, kereste ve parke işletmelerinin ise en yüks ek oranda bu sorunu yaşadıkları tes pit edilmiştir.

İşletmelerin dış ticaret yaparken herhangi bir kurum ya da kişiden destek alıp almaması ile diş ticaret uygulamaları arasında yer alan bürokrasiden kaynaklı olarak yaşanan sorunlar yaşama yargısı aras ında yapılan Ki-kare analizine göre istatistiksel olarak bir ilişki tespit edilmiştir $(p<0,05)$. Dış ticaret yaparken herhangi bir kurum ya da kişiden destek almayan işletmelerin daha yüksek oranda bürokrasiden kaynaklı sorunlar yaşadığı tespit edilmiş tir.

\section{Sonuç ve Öneriler}

Çalışma sonucunda dış ticaret yapan Batı Karadeniz Bölgesi orman ürünleri sanayi işletmelerinin yarıdan fazlasının dış ticaret ile ilgili olarak işletmelerinden en az 1 tane dış ticaret elemanı çalıştırdığı belirlenmiştir. İşletmelerin yarıya yakınının diş ticaretle ilgili olarak herhangi bir kurumdan/işletmeden teknik destek aldıkları tespit edilmiştir. İşletmelerin en az 1, en fazla da 12 fraklı ülkeyle dış ticaret gerçekleştirdikleri görülmüştür. İşletmelerin dış ticaret yaparken ağırlıklı olarak karayolu ile nakliye faaliyetlerinin yaptıkları belirlenmiştir.

Dış ticaret yapan işletmelerin \%67.3'ünün ürünlerde kendi markalarını kullandıkları belirlenirken, \%22.4'ünün sipariş veren dış ticaret firmasının markasının ürünlerinde olduğunu belirttiği görülmüştür.

Batı Karadeniz Bölgesi orman ürünleri sanayi işletmeleri için dış ticarette karşılaşılan en önemli sorunların başında elverişsiz kur oranlarından işletmelerin etkilendiği belirlenmiştir. Bunun yanında dış ticaret yapılan ülkeler arası siyasi ilişkilerin de diş ticaret üzerinde çok önemli etkiye sahip olduğu belirlenmiştir.

Çalışma kapsamında ele alınan orman ürünleri sanayi işletmelerin dış ticaret uygulamaları sırasında yaşadıkları 
sorunların başında ise maliyetlerle ilgili sorunların geldiği belirlenmiştir. Dış ticaret uygulamalarında işletmelerin dış ticaretle ilgili vergilerden ve uygulanan teşvik politikalarından kaynaklı olarak da önemli sorunlar yaşadıkları belirlenmiştir. Çalışma kapsamında işletmelerin bürokrasiden kaynaklı sorunlar yaşadıkları, finansal sorunlar yaşadıkları ve hedef pazara girişte yaşanan sorunlar yaşadıkları da gözlemlenmiştir.

İşletmelerin dolayısıyla da ülkelerin uluslararası rekabetinde başarı sağlayabilmesi için gümrük işlemlerinin etkinliği arttırılmalı ve kolaylaştırılmalı ve bunun içinde dış ticarette en önemli konulardan birisi olan bilgiye ulaşmada işletmelere kolaylıklar sağlanmalıdır. Ayrıca özellikle küçük ölçekli işletmelere finansal destekler konusunda yardımcı olacak teşviklerin verilmesi gerekmektedir.

Dış ticaretin geliştirilebilmesi için işletmelerde dış ticaret eğitimleri düzenlenmelidir. Bu eğitimler vasıstasıyla işletmelerin yaşadıkları olumsuzlukların ortadan kaldırılması sağlanmalıdır. Bunun yanında işletmelere reklam faaliyetleri için destekler verilmeli böylece işletmelerin ürettikleri ürünler için yurtdışında tanıtım imkânları sağlanmalıdır. İşletmelerin hem işletmelerini hem de ürettikleri ürünleri tanıtabilecekleri uluslararası fuarlara katılmaları için gerekli destekler sağlanmalıdır.

\section{Bilgilendirme}

Bu çalışma, Özge ÖZTÜRK tarafından hazırlanan, Düzce Üniversitesi, Fen Bilimleri Enstitüsü, Orman Endüstri Mühendisliği Anabilim Dalı'nda "Dış Ticaret Yapan Orman Ürünleri Sanayii İşletmelerinin Karşılaştıkları Sorunların Analizi (Batı Karadeniz Bölgesi Örneği)” isimli Yüksek Lisans tezinden üretilmiştir.

\section{Kaynaklar}

1. Ahçesi, S., (2019). KOBİ'lerde Dış Ticaretin Kolaylaştırılması ve Geliştirilmesi İçin Devlet Teşvikleri ve Uluslararası Çalışmaların Arttırılması İle Ülke Ekonomisine Sağlanacak Olumlu Katkılar, Doktora Tezi, İstanbul Ticaret Üniversitesi, Dış Ticaret Enstitüsü, İstanbul, 250 s.

2. Akan, Ü. (2021). Türkiye'de Dış Ticaret ve Lojistik Faktörü. Yüksek Lisans Tezi, Pamukkale Üniversitesi, Sosyal Bilimler Enstitüsü, Denizli, 114 s.

3. Akbulut G., Sekmen O. (2015). "Ulus lararası ticaretin gelişmesinde ulaşım maliyetlerinin rolü: Türkiye Örneği”, Balkan ve Yakın Doğu Sosyal Bilimler Dergisi, I(1), 20-29.

4. Aktaş, N. (2017). Türk Dış, Ticaret Sistemi ve Yapısının İncelenmesi. Yüksek Lisans Tezi, İstanbul Ticaret Üniversitesi, Dış Ticaret Enstitüsü, Uluslararası Ticaret Anabilim Dalı, İstanbul, 181 s.

5. Akyüz K.C., Balaban Y., Gedik T., Yıldırım İ. (2006). “Türkiye’nin orman ürünleri dış ticareti üzerine bir araştırma”, G.Ü. Kastamonu Orman Fakültesi Dergisi, 6(2), 179-197.

6. Anonim, (2019). Türkiye Odalar Borsalar Birliği, Sanayi Bilgi Sitemi Üye Kayıtları Listesi.

7. Bakan, İ. (2012). Dış Ticaret İşlemler ve Uygulamalar, Gazi Kitapevi, Ankara.

8. Çetinkaya Bozkurt, Ö., Tunç, H. (2018). KOBI'lerde diş ticaret sorunları: Antalya ili örneği. Uluslararası Yönetim İktisat ve İşletme Dergisi, 14(2), 381-398. DOI: 10.17130/ijmeb.2018239938

9. Çoban, Y. (2005). Kayseri mobilya sanayinin dış ticaret yapısı ve sorunlarına yönelik bir araştırma, Karamanoğlu Mehmetbey Üniversitesi Sosyal Ve Ekonomik Araştırmalar Dergisi, 2005(2), 73-82.

10. Erdoğan, Z., Develioğlu, K. (2009). Girişimcilik ve KOBI'ler Teori ve Uygulama. Zafer Erdoğan (ed.), 2. Baskı, Bursa: Ekin Basım Yayın Dağıtım.

11. Kabal, A.K., (2007). 1980-2005 Yilları Arasında Uygulanan Ekonomik Politikalar ve Bunların Dış Ticaret Üzerindeki Etkileri, Yüksek Lisans Tezi, Atatürk Üniversitesi, Sosyal Bilimler Enstitüsü, Erzurum, $75 \mathrm{~s}$.

12. Kalaycı, Ş. (2009). SPSS Uygulamalı Çok Değişkenli İstatistik Teknikleri. Asil Basın Yayın Dağıtım, Ankara, Türkiye.

13. Karluk, S.R., (1991). Uluslararası Ekonomi, Geliştirilmiş 3.B., Bilim Teknik Yayınevi, İstanbul.

14. Kaymak, O. (2015). Türkiye'deki KOBİ'lerin Mevcut Durumlarının Analizi ve Ticari Uygulamalar1. Yüksek Lisans Tezi, Dicle Üniversitesi, Sosyal Bilimler Enstitüsü, Diyarbakır, 133 s.

15. Ketboğa, M., (2020). Dış Ticaretin Yapısal Sorunları, Bu Sorunların Firmaların Faaliyetleri Üzerindeki Etkileri: Malatya Örneği, Doktora Tezi, İnönü Üniversitesi, Sosyal Bilimler Enstitüsü, Malatya, 175 s.

16. Köksal, M. (2016). Dış Ticaret ve Ekonomik Büyüme İlişkisi: Türkiye Örneği. Yüksek Lisans Tezi, Selçuk Üniversitesi, Sosyal Bilimler Enstitüsü, Konya, 133 s.

17. Köksal, M. H. Kettaneh, T. (2011). Export problems experienced by high-and low- performing manufacturing companies: A comparative study. Asia Pacific Journal of Marketing and Logistics, 23(1), 108-126. 
18. Kumbas, S., (2017). KOBİ'lerin Dış Ticarette Karşılaştıkları Sorunlar, Yüksek Lisans Tezi, Adnan Menderes Üniversitesi, Sosyal Bilimler Enstitüsü, Aydın, 89 s.

19. Lemeshow, S., Hosmer, Jr.D.W., Janelle, K., Lwanga, S.K. (1990). Adequacy ofSample Size in Health Studies, Published by World Healt Organization. Tiptree, Colchester, ISBN: 047192517 9, Courier International Ltd.

20. Leonidou, L. (1995). Export barriers: non-exporters’ perceptions. International Marketing Rev., 12(1), $4-25$.

21. Özdamar, K. (2002). Paket Programlar İle İstatistiksel Veri Analizi. Kaan Kitabevi, Ankara, (Türkçe).

22. Öztürk, A., Sandalcılar, A. R. (2018). Dış ticaret işlemlerinde tercih edilen ödeme yöntemleri: Doğu Karadeniz Bölgesi üzerine bir uygulama, Kastamonu Üniversitesi İktisadi ve İdari Bilimler Fakültesi Dergisi, 20(4), 201-218.

23. Saatçı, A., (2019). Arap Baharından Sonra Türkiye'nin Dış Ticaretinde Yaşanan Finansal Problemler, Yüksek Lisans Tezi, Hasan Kalyoncu Üniversitesi, Sosyal Bilimler Enstitüsü, Gaziantep, 143 s.

24. Sönmez, A., Arslan, A. (2007). İhracat yapma şekline göre karşıllaşılan sorunlar; mobilya endüstrisi örneği, Politeknik Dergisi, 10(4), 403-409.

25. SPSS, (2003). SPSS Base 12.0 User's Guide. Institute Inc.

26. Suri, R.K., Budhiraja, J.K., Rajput, N. (2006). A Text Book of ISC Economics. New Delhi: Vol II for Class XII.

27. Takım, A. (2015). Uluslararası ticarete giriş. Ekin Basım Yayın Dağıtım. Bursa.

28. Tokol, T. (1998). Pazarlama Yönetimi, Vipaş, 8. Baskı, Bursa.

29. Tunç, H. Kaya, M. (2017). Bölgesel kalkınmada dış ticaret sektörünün rolü ve sorunları: Batı Akdeniz Bölgesi örneği. Finans Politik \& Ekonomik Yorumlar, 54(627), 59-71.

30. TüIKK, (2020). İstatistik Veri Portal, Dış Ticaret İstatistikleri, https://data.tuik.gov.tr/Kategori/GetKategori?p=Dis-Ticaret-104.

31. TüiK. (2016). Küçük ve Orta Büyüklükteki Girişim İstatistikleri.

32. Yıldırım İ., Akyüz K.C., Gedik T., Balaban Y., Çabuk Y., (2008). Ahşap levha endüstrisinin Avrupa Birliği ülkeleri ile rekabet edebilirliği, ZKÜ Bartın Orman Fakültesi, 10(13), 11-22.

33. Yıldırım, İ., Gedik, T., Akyüz, K.C., Akyüz, İ., Aydın, A., (2005). Dış Ticaret Yapan Firmaların Karşılaştıkları Sorunlar ve Çözüm Önerileri (Trabzon İli Örneği), Doğu Karadeniz Bölgesi Kalkınma Sempozyumu, Trabzon, 13-14 Ekim 2005. s. 215-230, ss.518.

34. Yılmaz, Z., Eryılmaz, M. (2021). Türk dış ticaretinin yapısal dönüşümünün analizi (2002-2016). Internatıonal Journal of Afro-Eurasian Research (IJAR), 6(11), 87-101. 